\title{
Effects of Globalization on Economic Growth: A Case Study of Pakistan
}

\author{
Humaira Munir ${ }^{1} \quad$ Anam Javaid $^{2}$ Suleman Ghaffar ${ }^{3} \quad$ Shahbaz Nawaz ${ }^{4}$ \\ 1.MS Scholar Economics: UMT Lahore \\ 2.Lecturer, Department of Statistics, The Women University Multan, Pakistan \\ 3.M.Phil ; Public Administration, Department of ISS BZU Multan \\ 4.Visiting Lecturer, Bahauddin Zakariya University Multan, Pakistan
}

\begin{abstract}
The study examines the impact of total exports of goods and services, imports of goods and services, Foreign Direct Investment net inflows, GNI per capita, and inflation on the economic growth of Pakistan. The empirical analysis is conducted by using time series data from (1980-2012) from Pakistan. The ARDL technique is used to detect the relationship between exogenous variables and endogenous variable. The estimated results show that explanatory variables Exports, GNI and FDI have positive and significant impact on the economy of Pakistan. The results also show that an increase in the exports of Goods and services, the Foreign direct investment so that output of the country is boost up. Similarly, Inflation and Imports has negative influence on the economy of Pakistan. It concludes that international trade may play an important role to improve the economy of Pakistan.
\end{abstract}

Keywords: Economic growth; Imports; Exports; Inflation; Pakistan.

DOI: $10.7176 / \mathrm{IAGS} / 79-02$

Publication date: January $31^{\text {st }} 2020$

\section{Introduction}

Todaro and Smith (2003) have stated that globalization presents new possibilities for eliminating global poverty and globalization can benefit poor countries directly and indirectly through cultural, social, scientific and technological exchanges as well as trade and finance.

To reduce poverty and attain development in developing countries have been promoted by International Financial Institutions (IFIs) especially, International Monetary Fund (IMF) and World Bank (WB) since their foundation. In $1950 \mathrm{~s}$ and $1960 \mathrm{~s}$ the main focus of trickle-down theory was to achieve high growth rates. Industrialization was the mechanism for enhanced growth rate and in this era agriculture suffered at the expense of industry and terms of trade worsened against agriculture. At the end of 1960s, IFIs realized that their overemphasis on achieving high growth rates was problematic in the sense that least developed countries (LDCs) showed poor performance on human indicators. In these policies growth was still important and considered to be a necessary condition for sustained development, but countries were advised to look after their poor and provide basic facilities to them as well. After the debt crisis in 1980s, many countries experienced extremely high inflation.

Globalization factors that are external to an individual nation may facilitate trade. Technological changes may make certain goods, imports for example, cheaper despite the presence of trade restrictions. Similarly, a fall in transportation costs or the end of war may alter the relative price of tradable encouraging greater international trade. Trade may increase income, but changes in trade policies may not foster increased international trade and hence not contribute to growth or poverty reduction. The government functions were limited and faced many constraints like gold standard and lack of freedom to pursue easy monetary policy. Later governments were burdened by performing many functions like achievement of macroeconomic goals full employment, economic growth and price stability. Freedom of using macroeconomic policies resulted in greater integration of national economies but at the same time they led to international disintegration and interdependence.

Globalization refers to the growing interdependence of countries guarantying from the growing trends in trade, finance and ideas in one global marketplace. International trade and cross-border investment flows are the main elements of this integration. Globalization started after World War II but has speed up extensively in the mid of 1980's. Two main drivers of globalization are technological advancement and liberalization. Pakistan got independence in 1947 and Malaysia got independence in 1957. Since independence, average economic growth rate of Pakistan is higher than the average economic growth rate of the world economy. Due to low demand for exports Pakistan's international trade is bearing huge deficit. In Pakistan, political instability is also responsible for deficit in trade. In 2010 Pakistan, trade deficit reached at US \$ billion. To reduce this deficit and liberalize the trade and investment in country some steps have been taken such as tariff increased from 20 percent- 25 percent to 30 percent-35 percent which decreased trade deficit in 2009 US $\$ 9.261$ billion to US $\$ 3.946$ billion in 2010.

Globalization and its impact on world economic development analyzed by many explanatory variables such as FDI, PCI, Employment and other social indicators that shows a positive relation of all these indicators with 
globalization and world economic development (Akram ch et al 2009). Export-oriented FDI has brought noteworthy profits (Authokorala et al 1996). Trade, investment promoting and poverty alleviating policies have significant positive impact to promote economic growth in Pakistan (Fatima et al 2012). In the MalaysiaPakistan Business Forum held at Kuala-Lumpur Husain (2005) Address delivered that trade, technological and financial cooperation of Pakistan with Malaysia can be of enormous value for both countries economy.

All previous researches are about examining developing countries or countries comparison but the purpose of our research to provide a proper way to promote economic growth in Pakistan by enhancing Pakistan's export. Pakistan is still an emerging economy, by adopting Malaysian economic policies it can improve its economic growth. This study highlighting the key factors of economic growth that how we can achieve a sustainable growth by introducing beneficial trade policies? How inflation and import have negative effect on economic growth? Answers of such these questions we will try to find in this research.

Pakistan is a country which also rich in its agricultural and natural resources. Pakistan's economy also need to adopt and implement these policies to expand the export growth rate in country and promote industrial sector to reduce poverty in country and enhancing economic growth in Pakistan. There is a need of political stability and proper implementation of policies.

\section{Objective of the Study}

The main object of this study is to analyze the combine relationship among economic growth with Gross national income, foreign direct investment, Inflation, Exports and Imports.

All previous researches discussed separate relationship among all these variables but this research is about that how one variable affects other variable. The hypothesis of this study is trade globalization and economic growth that are positively related with each other. The main objectives of this research are:

$>$ To see the effects of foreign direct investment, exports and imports on economic growth of Pakistan.

$>$ To examine the relationship between inflation and economic growth.

$>$ To examine the relationship between Gross national income and economic growth.

$>$ To suggest some policies for increase in economic growth

\section{Organization Scheme of the study}

- First Section is introduction which gives brief overview that what is our topic and what researches before this had done related to our topic and what we will try to find in this study.

- Second Section of this study is literature review which is about previous studies and their results and policy recommendations.

- Third Section is methodology which tells about variables specification and time span of our data and data type and source of data.

- Fourth Section is data analysis which consist on implication of statistical techniques that we will apply on our data to check the significance of our research.

- Fifth Section is conclusion or policy recommendation that shows that what we conclude from our research and what policies we are suggesting on the base of our study.

\section{Literature Review}

Chang and Lee (2010) analyzed the connection between general globalization index and its components, which are economic, social and political globalization indexes, and the economic growth of 23 OECD countries, whose data is collected between years 1970 and 2006, with the help of cointegration analysis. The result of the analysis show that there is a weak connection between variants and causality in short terms but in long terms there is a one way connection from general, economic and social globalization to economic growth. Polasek and Sellner (2011) analyzed globalization's effects on the regional growth of 27 European Union (EU-27) countries, data of which is collected between the years 2001 and 2006, by using the Spatial Chow-Lin Procedure, which was formed by writers. Polasek and Sellner (2011) found out that globalization, thanks to the trade gap and direct foreign investment, and affect many regions' economic growth in a positive way. Rao (2011) analyzed the connection between globalization and economic growth for Singapore, Malaysia, Thailand, India and Philippines in the extent of Slow (1956) growth model. According to the results of the research; as the globalization grows in these countries, the growth percentages of stabilized status goes higher too.

Authokorala et al (1996) overviewed the impact on economic growth and development in Malaysia with respect to foreign investment, globalization and trade. To check the link among these variables they used panel data in their study. After analyzing in detail they conclude that Malaysia achieved a remarkable growth and development in developing world in last two decades. Malaysian growth to a great extent export and foreign investment oriented. The study of suggested that other developing countries like Pakistan should adopt the right policies to promote their export, industrialization and attract foreign investment in their country to achieve growth and development and to break down the vicious circle of poverty and low growth. 
Duasa (2008) scrutinized in his study relationship between foreign direct investment and economic growth in perception of Malaysia. He used quarterly time series data 1990-2002 consist of 52 observations and imply ADF and P-P unit root test, ARCH model, BDS test and ARMA (Autoregressive model) to analyze the data. Findings of the study of this study show that presence of one variable enhances the permanence of another variable. The policy suggestions according to these results as to advancement in GDP and FDI (net inflows) and stability in income should be encouraged by policymakers and make policies to attract FDI in country and promote economic growth and development.

Fatima et al (2012) examined the link among trade, investment, and poverty in case of Pakistan. In this study they used poverty as dependent variable and trade and investment, POP, FDI, GDP and CPI as independent variables with the respect to Pakistan. Researchers of this study used time series annually data of 30 years 1980-2009. They used ADF test and P-P unit root test, Johansen co-integration test and ECM (Error Correction Model) to investigate the belongings of fixed values. The results of the tests proposed that trade; investment, economic growth and foreign direct investment trim down poverty. Methodological study illuminated that investment is a solution to encourage economic growth and trade openness gives direction to a persistent economic growth in Pakistan. Policymakers have the same opinion on guiding principle to deal with economic growth in respect of poverty.

Javed et al (2012) inspected the effects of international trade on economic growth with the reference of Pakistan. They defined economic growth as dependent variable and investment to GDP ratio, trade openness, imports to GDP ratio, exports to GDP ratio and terms of trade as independent variables. They used time series data of 37 years 1973-2010 to verify the impact of international trade on economic growth. They used ADF (Unit Root Test), White test,Breusch- Godfray test and Durbin Watson d-test to examine the effect of international trade on economic growth of Pakistan. The results of this study showed that by rising up the import of raw material, the output of the country would get better. Trade openness has direct and considerable impact on Pakistan's economy. To improve the economic growth of Pakistan government needs to play a sound role. Government should adopt perfection in tax and tariff policies to cut down the import of costly goods with proper substitute policies and also needs to spotlight economic and structural amendment policies to make them superior for economic growth of Pakistan

\section{Data Source and the Methodological Framework}

\section{Data Source}

The data on Exports and imports of goods and services, Foreign Direct investment, GNI, real GDP and Inflation, have been taken from the World Bank (2016). Using the annual data the sample period ranges from 1980 to 2012. The above mentioned variables like: imports, exports, GNI per capita and per capita gross domestic product have constant local currency units, whereas, the inflation is on annual percent. The foreign direct investment net inflows taken as ratio of GDP.

The Methodological Framework

In this study the double logged model is used because log-form approach provide more efficient estimates as compared to simple form approach [Ehrlich (1977), Layson (1983), Bowers and Pierce (1975), Cameron (1994) and Ehrlich (1996)].

The models are proposed as:

$$
\ln G D P t=a 0+a 1 t \ln E X P t+a 2 t \ln I M P T t+a 3 t \ln I N F t+a 4 t \ln F D I t+a 5 t \ln G N I+\lambda l t
$$

Whereas; the construction of each variable along with its sample period is presented below:

Table 1: Variable Source

\begin{tabular}{|c|c|c|c|c|}
\hline $\begin{array}{l}\text { Variable } \\
\text { Representation }\end{array}$ & $\begin{array}{l}\text { Variable } \\
\text { Name }\end{array}$ & Proxy for & $\begin{array}{l}\text { Variable } \\
\text { Construction }\end{array}$ & Source \\
\hline $\ln G D P$ & $\begin{array}{l}\text { Per Capita } \\
\text { Real GDP }\end{array}$ & $\begin{array}{l}\text { Economic } \\
\text { Growth }\end{array}$ & $\begin{array}{l}\text { Ln(Real GDP/Total } \\
\text { pop) }\end{array}$ & $\begin{array}{l}\text { WDI } 2016 \\
1974-2015\end{array}$ \\
\hline $\operatorname{lnIMP}$ & Imports of goods and services & Imports & Ln(imports) & $\begin{array}{l}\text { WDI } 2016 \\
1974-2015 \\
\end{array}$ \\
\hline $\ln E X P$ & Exports of goods and services & Exports & Ln(Exports) & $\begin{array}{l}\text { WDI } 2016 \\
1974-2015\end{array}$ \\
\hline $\ln G N I$ & Gross National income per capita & GNI & $\operatorname{Ln}(\mathrm{GNI})$ & $\begin{array}{l}\text { WDI } 2016 \\
1974-2015\end{array}$ \\
\hline $\ln F D I$ & $\begin{array}{l}\text { Foreign direct investment, net } \\
\text { inflows }(\% \text { of GDP) }\end{array}$ & FDI & $\operatorname{Ln}(\mathrm{FDI})$ & $\begin{array}{l}\text { WDI } 2016 \\
1974-2015\end{array}$ \\
\hline $\operatorname{lnINF}$ & 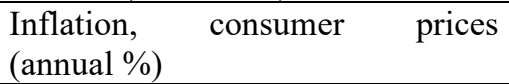 & Inflation & $\operatorname{Ln}(\mathrm{INF})$ & $\begin{array}{l}\text { WDI } 2016 \\
1974-2015\end{array}$ \\
\hline
\end{tabular}




\section{Estimation Technique}

In order to investigate factors which affect the Gross domestic product in Pakistan, different econometric tools are used in the study. Initially; the unit root problem is examined after identifying the order of integration of the data series and then the long-run cointegration between imports and its predictors is tested. Besides finding the long run co-integration, the impact of each predictor in the long-run and in the short-run is found. All these econometric steps are discussed as under:

\section{Testing the Unit Root Problem}

The unit root problem is tested by using the KPSS (1992) unit root test. This test is more suitable and efficient for small number of observations. The null hypothesis series is stationary against the alternate hypothesis that series is non-stationary.

\section{Testing the Co-Integration}

The long-run co-integrating relationship between the real imports and its predictors is found by using the ARDL bounds testing approach which was introduced by Pesaran et al. (2001). This co-integration technique is more consistent for small number of observations and for the data series which reports mixed order of integration. The null hypothesis of no co-integration is tested against the alternative hypothesis of co-integration by the F-test which is found by using the Schwarz Bayesian Criterion. If the estimated value of F-test is greater, the upper critical bound rejects the null hypothesis and accept the alternative hypothesis. Therefore, it is concluded that the long-run co-integrating relationship between the Economic Growth and its predictors will exist. If the estimated value of F-test becomes less than the lower critical bound the null hypothesis is accepted. It will therefore be concluded that there is no long-run relationship between the Economic growth and its factors. Moreover, if the estimated value of F-test is found in between the lower and upper critical bounds, then in this case, the test becomes inconclusive, meaning that no decision can be taken about long-run relationship between the economic growth and its factors.

Besides finding the long-run co-integrating relationship and the long-run coefficients, the short-run coefficients is examined, using Error Correction Model.

\section{Results and Discussions}

In this part of the study; the empirical results for conceptualized models and their discussion are presented. The analysis starts from estimating descriptive statistics of both predictors and outcome variables of this study. The results are shown in Table 2.

TABLE 2: Descriptive Statistics

\begin{tabular}{|l|l|l|l|l|l|l|}
\hline & LNFDI & LNINF & LNEXP & LNGNI & LNGDP & LNIMP \\
\hline Mean & -0.37033 & 2.048917 & 27.05581 & 10.66855 & 10.63733 & 27.66375 \\
\hline Median & -0.44398 & 2.179053 & 27.13749 & 10.64812 & 10.65654 & 27.64566 \\
\hline Maximum & 1.299735 & 3.009937 & 27.88408 & 10.96151 & 10.91276 & 28.21764 \\
\hline Minimum & -2.27627 & 1.069573 & 25.92937 & 10.35239 & 10.26462 & 27.14999 \\
\hline Std. Dev. & 0.814144 & 0.488526 & 0.592597 & 0.17195 & 0.189662 & 0.310078 \\
\hline Skewness & 0.05987 & -0.42434 & -0.32547 & 0.179548 & -0.19906 & 0.249352 \\
\hline Kurtosis & 2.998153 & 2.380937 & 1.986649 & 2.128073 & 2.120838 & 2.051804 \\
\hline Jarque-Bera & 0.019719 & 1.517285 & 1.994577 & 1.222659 & 1.280715 & 1.578199 \\
\hline Probability & 0.990189 & 0.468302 & 0.368878 & 0.542629 & 0.527104 & 0.454254 \\
\hline Sum & -12.2208 & 67.61425 & 892.8417 & 352.0621 & 351.0319 & 912.9037 \\
\hline Sum Sq. Dev. & 21.21058 & 7.63704 & 11.2375 & 0.946142 & 1.151088 & 3.076756 \\
\hline Observations & 33 & 33 & 33 & 33 & 33 & 33 \\
\hline
\end{tabular}

Table 2 reveals the fundamental information regarding the factors of the study. In the following table, the mean, median and standard deviation (among others) are reported.

The J.B test was not significant and showed that all the factors into this study is normally distributed.

After discussing the descriptive statistics of all predictors and outcome variables, the stationarity of data series using KPSS (1992) unit root test are estimated. KPSS (1992) is efficient test for small number of observations. The null hypothesis test states that data series is stationary whereas alternative hypothesis shows that series is non-stationary. Estimated results of this test are shown in Table 3. From Table 3 it can be viewed that KPSS unit root test has been tested at level and at first difference for the sample period from 1980 to 2012 ; hereafter, it may be concluded that the estimated value of KPSS unit root test for GNI per capita and GDP per capita, has been found greater than its corresponding critical value at one per cent level of significance.

The null hypothesis for these two variables is rejected and it is conclude that these two variables are found to be non-stationary at level. However; the estimated values of KPSS unit root test for Exports and imports of 
goods and services, Inflation and Foreign direct investment net inflows (\% of GDP) have found to be less than the corresponding critical value at one per cent level of significance at level. Therefore, the null hypothesis may be accepted and it may be concluded that these four variables have found to be stationary at level.

Table 3: KPSS Unit Root Test

\section{KPSS UNIT ROOT TEST}

\begin{tabular}{|c|c|c|c|c|c|}
\hline Variables & At Level & Decision & Variables & $\begin{array}{l}\text { At First } \\
\text { Difference }\end{array}$ & Decision \\
\hline $\ln G D P$ & 0.752943 & Non Stationary & $\triangle \ln G D P$ & 0.231558 & Stationary \\
\hline $\operatorname{lnIMP}$ & 0.699345 & Stationary & $\Delta \ln I M P$ & 0.072705 & Stationary \\
\hline $\ln E X P$ & 0.734896 & Stationary & $\Delta \ln E X P$ & 0.225433 & Stationary \\
\hline $\ln G N I$ & 0.748637 & Non Stationary & $\Delta \ln G N I$ & 0.112701 & Stationary \\
\hline $\ln F D I$ & 0.508040 & Stationary & $\Delta \ln F D I$ & 0.169420 & Stationary \\
\hline $\operatorname{lnINF}$ & 0.087865 & Stationary & $\Delta \operatorname{lnINF}$ & 0.092379 & Stationary \\
\hline \multicolumn{6}{|c|}{ Asymptotic Critical Values of Kwiatkowski-Phillips-Schmidt-Shin Unit Root Test } \\
\hline \multicolumn{6}{|c|}{$\begin{array}{l}\text { ISignificance Level } \\
05 \text { Per cent } 0.4630\end{array}$} \\
\hline
\end{tabular}

Furthermore; the estimates of KPSS unit root test for all six variables of the study at first difference have shown that the estimated LM-test for all the six variables has found to be less than the corresponding critical value at one per cent level of significance. The null hypothesis is accepted and it is concluded that all these variables are stationary at first difference. Therefore, Table 3 concludes that some variables are stationary at level and some are stationary at first difference. Thus, the data series of the present study has mixed order of integration like $\mathrm{I}(0)$ and $\mathrm{I}(1)$. Thereafter, in order to investigate the long-run co-integration between the GDP per capita and its predictors the ARDL bounds testing approach was applied. The estimated results are presented in Table.

It can now be viewed that estimates of ARDL bounds testing approach the conceptualized model; To find a long run relationship we have applied ARDL Bounds Testing Approach and the estimated results reported in Table confirm the existence of long run relationships between GDP and its factors as F - statistic has found to be greater than the upper critical bound at $5 \%$ level of significance.

The estimated results from Table 4 show that the calculated value of $\mathrm{F}$ test is 5.4048 which is greater than its corresponding critical value 4.5050 at $5 \%$ level of significance, therefore, this confirms the evidence of long run cointegration between Economic Growth and its factors like Exports of goods and services, GNI per capita, Imports of goods and services, Inflation and Foreign direct investment, net inflows (\% of GDP). The estimated probability values of the chi-square tests for all the diagnostics tests were not found to be significant which revealed that there are no serial correlation and heteroscedasticity problems in this study. Moreover, the error term of the selected ARDL model is normally distributed and the functional form of the selected ARDL model is also correctly specified. 
Table 4: ARDL Regression

\begin{tabular}{|c|c|c|c|c|}
\hline \multicolumn{3}{|l|}{ Estimated Models } & \multicolumn{2}{|c|}{ GDPt $=\mathrm{f}(\mathrm{EXPt}, \mathrm{IMPt}, \mathrm{INFt}$, FDLt,,GNIt) } \\
\hline \multicolumn{3}{|l|}{ Optimal lags } & \multicolumn{2}{|c|}{$(1,0,0,0,0,0,0)$} \\
\hline \multicolumn{3}{|l|}{ F-statistics } & \multicolumn{2}{|l|}{5.4048} \\
\hline \multicolumn{3}{|l|}{$W-$ statistics } & \multicolumn{2}{|l|}{32.4289} \\
\hline \multirow[t]{2}{*}{ Significance Level } & $\begin{array}{l}\text { Critical } \\
\text { Statistic }\end{array}$ & Bounds for $F$ - & \multicolumn{2}{|c|}{ Critical Bounds for $W-$ Statistics } \\
\hline & $\begin{array}{l}\text { Lower } \\
\text { Critical } \\
\text { Bound }\end{array}$ & $\begin{array}{l}\text { Upper Critical } \\
\text { Bound }\end{array}$ & $\begin{array}{l}\text { Lower Critical } \\
\text { Bound }\end{array}$ & $\begin{array}{l}\text { Upper Critical } \\
\text { Bound }\end{array}$ \\
\hline 5 per cent & 3.0876 & 4.5050 & 18.5256 & 29.4318 \\
\hline 10 per cent & 2.5804 & 3.8000 & 15.4821 & 22.7999 \\
\hline $\mathbf{R}^{\mathbf{2}}$ & \multicolumn{2}{|l|}{.99779} & Serial Correlation & $\begin{array}{l}.089977 \\
{[.764]}\end{array}$ \\
\hline Adjusted - $\mathbf{R}^{2}$ & \multicolumn{2}{|l|}{.99728} & Functional Form & $\begin{array}{l}2.0777 \\
{[.149]}\end{array}$ \\
\hline F - Statistics & \multicolumn{2}{|l|}{1957.8} & Normality & $\begin{array}{l}1.5347 \\
{[.464]}\end{array}$ \\
\hline $\begin{array}{l}\mathbf{P}-\text { Value } \\
\text { Statistics }]\end{array}$ & \multicolumn{2}{|l|}{0.000} & Heteroscedasticity & $\begin{array}{l}.14856 \\
{[.700]}\end{array}$ \\
\hline DW - Statistic & \multicolumn{2}{|l|}{1.8156} & Durbin H - Statistic & $\begin{array}{l}.55963 \\
{[.576]}\end{array}$ \\
\hline
\end{tabular}

Also the values within [ ] represents Probability Values.Afterwards, the long run and short run coefficients of Economic Growth along with other controls have also been estimated, and the results have been presented in Table 5

Table 5: Long Run coefficients and ECM

\begin{tabular}{|c|c|c|c|}
\hline \multicolumn{2}{|c|}{$\begin{array}{l}\text { Estimated Long Term Coefficients } \\
\text { using the ARDL Approach }\end{array}$} & \multicolumn{2}{|c|}{$\begin{array}{l}\text { Error Correction Representation } \\
\text { for the Selected ARDL Model }\end{array}$} \\
\hline \multicolumn{2}{|c|}{ Dependent Variable: LNGDPt } & \multicolumn{2}{|c|}{ Dependent Variable: $\ddot{A} L N G D P t$} \\
\hline Variables & $\begin{array}{l}\text { Coefficient } \\
{[P-\text { Value] }}\end{array}$ & Variables & $\begin{array}{l}\text { Coefficient } \\
\text { [P-Value] }\end{array}$ \\
\hline LNEXP & $\begin{array}{l}.080309 \\
{[.007]}\end{array}$ & $\Delta \operatorname{lnEXP}$ & $\begin{array}{l}.038853 \\
{[.015]}\end{array}$ \\
\hline LNIMP & $\begin{array}{l}-.028315 \\
{[.493]}\end{array}$ & $\Delta \operatorname{lnIMP}$ & $\begin{array}{l}-.013699 \\
{[.489]}\end{array}$ \\
\hline LNINF & $\begin{array}{l}-.011988 \\
{[.161]}\end{array}$ & $\Delta \operatorname{lnINF}$ & $\begin{array}{l}-.0057996 \\
{[.163]}\end{array}$ \\
\hline LNFDI & $\begin{array}{l}.026208 \\
{[.005]}\end{array}$ & $\Delta \ln \mathrm{FDI}$ & $\begin{array}{l}.012679 \\
{[.004]}\end{array}$ \\
\hline LNGNI & $\begin{array}{l}.75073 \\
{[0.000]}\end{array}$ & $\Delta \ln \mathrm{GNI}$ & $\begin{array}{l}.36320 \\
{[.000]}\end{array}$ \\
\hline $\mathrm{C}$ & $\begin{array}{l}1.2959 \\
{[0.055]}\end{array}$ & $\mathrm{ECM}_{\mathrm{t}-1}$ & $\begin{array}{l}-.5001 \\
{[.000]}\end{array}$ \\
\hline
\end{tabular}

The estimates for long term and short term coefficients reported in Table 6 demonstrate that foreign direct investment, net inflows (\% of GDP) has a significant and positive impact on Economic growth in the long term and in the short term in Pakistan. It is also evident that Imports of goods and services is insignificantly curtailing Economic growth into long term and short term, the coefficient of imports have found to be negative. The Inflation gives negative and insignificant impact on Economic growth and as we see GNI have positive and significant impact on economic growth.

After examining the short-run coefficients the stability test is applied to see whether coefficients of predictors of value of Economic Growth are stable over time or if there is any structural instability in the conceptualized models. For this purpose, the CUSUM and CUSUM squared graphs are used. If the graphs of CUSUM and CUSUM squared are found within their critical bounds, then it would be concluded that the estimated parameters or coefficients over time are stable. Moreover; the stability of CUSUM refers to the stability of mean of error term over time and the stability of CUSUM squared refers to the stability of variance of error term over time. The CUSUM and CUSUM Square are presented in Figure 1. 
Plot of Cumulative Sum of Recursive Residuals

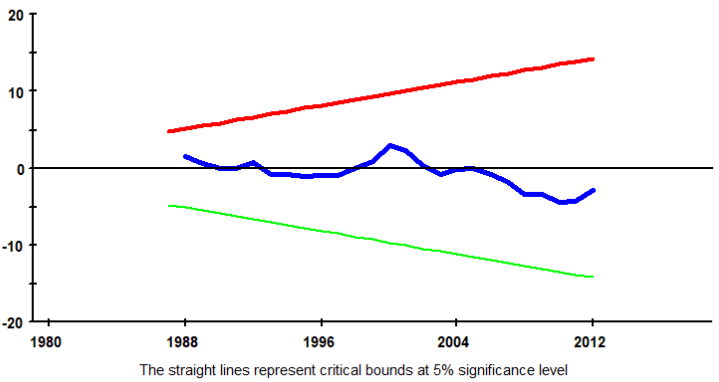

Figure 1: Plot of Cummulative Sum of Recursive Residuals

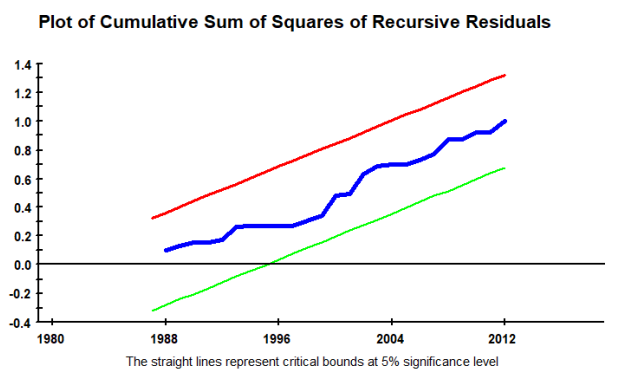

Figure 2: Plot of Cumulative Sum of Squares of Recursive Residuals

\section{Conclusion and policy implications}

This paper explores the factors which affect the Economic growth as share of real GDP in Pakistan. The study uses the annual data from 1980 to 2012, and applies the ARDL Bounds Testing Approach to identify and estimate the long-run relationship.The study also uses the error correction model to estimate the short-run coefficients and speed of adjustment. To check the stability of estimated parameters, the study applies the CUSUM and CUSUM of squares residual plots. Using the two specifications the study finds that predictors of Economic growth have co-integrating relationship with each other. Moreover; the study also finds that Exports of goods and services and foreign direct investment have significant and inspiring effect on Economic growth in Pakistan. All coefficients have signs in line with theory and intuition except inflation and Imports having negative sign which means that when domestic inflation increases, imports go down so the adversely impact on economic growth.

To be buoyant about the results of this study, the stability test was also run. Findings of the stability test have confirmed that the predictors of Economic growth for the selected sample period are structurally stable. These results have policy implications to improve the trade performance. Particularly, Negative inflation suggests that to improve trade balance so the economy boost up.

In short, international trade has positive impact on the economy of Pakistan. The economy Pakistan can be better if Government should adopt multipurpose strategies such as improvement in tax and revenue structure, improving fiscal, monetary policies and structural adjustments policies and eradicate anticompetitive market practices. Moreover, Govt should decrease the imports of costly products with suitable policies and prefer to prepare all required things inside the country.

\section{References}

Authokorala and Menon (1996). Foreign Investment and Industrialization in Malaysia: Exports, Employment and Spillovers. Asian Economic Journal, 10(1), 29-44.

Duasa (2008). Malaysian Foreign Direct Investment and Growth: Does Stability Matter?" Journal of Economic Cooperation, 28(2), 83-98.

Fatima, Shahbaz and Islam (2012). Nexus of Trade, Investment and Poverty: Evidence from Pakistan. Bangladesh Development Studies, MPRA, XXXV(2), 87-108.

Javed, Mushtaq, Ullaha and Iqbal (2012). Effects of International Trade on Economic Growth: The Case Study of Pakistan. International Journal of Academic Research in Progressive Education and Development, 1(2), $103-113$. 